$\xi=-1$

\title{
Design Development Learning Media Based PMRI Oriented Capabilities Study Creative Students Grade VII of Junior High School in Indonesia
}

\author{
Fatim Isdiarti ${ }^{1 *}$, Suparman ${ }^{2}$ \\ ${ }^{1,2}$ Masters of Mathematics Education, University of Ahmad Dahlan Indonesia \\ *Corresponding author E-mail: fatimisdiarti14@gmail.com
}

\begin{abstract}
Creative thinking ability of students' in solving math problems in Indonesia is still low since they have not been able to use their learning experience yet. To train the students to be creative, it is required learning tools that can provide a memorable learning experience. One of the learning tools is the student worksheet.Indonesian Realistic Mathematics Education (RME) is a learning approach that emphasizes on a memorable learning experience. This research is an effort to develop Indonesian RME to improve students' creative thinking ability. It was a development research with four-D model-- define, design, develop, disseminate. This study was limited to the design stage only. The subjects of the research were the students of class VII MTs Muhammadiyah Karangkajen Yogyakarta Indonesia. Instruments used to retrieve data were the validation of the Lesson Plan, the Student Worksheet, and the creative thinking ability test. The results indicate that the student worksheet design is suitable for student characteristic and curriculum 2013. Student worksheet can be used to improve students' creative thinking ability. Thus, further research on implementation and dissemination can be continued.
\end{abstract}

Keywords: Creative Thinking; Indonesian Realistic Mathematics Education; Student Worksheets.

\section{Introduction}

Among the key skills that must be owned by the 21st-century students are innovative learning, creative thinking, problemsolving skill, communication, and collaboration skills[1]. The teachers in the classroom should equip the students not only with rules and procedures but also strategies to express ideas in solving math problems [2]. As Khoule et.al said that the way of procedural teaching aggravates students' perceptions of mathematics [3]. If the students are drilled to solve problems, their creative thinking ability will be exacerbated or their thinking ability in solving mathematical problems will be reflected in their problem solving [4]. In the real context, however, the students have weaknesses in terms of creative thinking skills, including in solving math problems, in which the students do not have the ability to develop new ways to solve problems, lack of understanding in applying concepts, unable to give different answers, disable to develop or enrich existing ideas, and significantly less able to express the explanation of particular reason [5].

The ability to think creatively is necessary for mathematics students as it is a field of science that teaches abstract objects [6]. In other words, the difficulty to understand and master mathematics is still a serious problem especially for junior high school students [7].As the results, difficulties in understanding mathematics influence their mathematics achievement both nationally and internationally. At the national level, for example, their average mathematics score in 2017 was the lowest compared to the other three subjects (maths $=47.75$, Bahasa Indonesia $=70.20$, English $=49.08$, and Science=51.97[8]. Then in the international achievement, during the competition of PISA 2015, the score of Indonesian students was 386 which was still below the International average of 490 [9]. Unsatisfactory results were also obtained at the mathematics Olympic competition wherein 2017 Indonesia was ranked 31 st which was lower than the rank in 2016 [10].

To improve mathematical achievement, the starting point is the teacher as he/she has direct contact with the students during the process of teaching and learning in the classroom [6]. This is in accordance with the 2013 Curriculum stipulated in Government Regulation No. 32 of 2013, Article 19 which says learning process is organized activity that is inspirative, enjoyable, and challenging; it should motivate learners to participate actively, and provide sufficient space for initiative, creativity, and independence according to the talents, interests, and physical and psychological development of learners [11]. Based on these regulations, teachers are required to design learning activities in accordance with the expected results.

In the attachment of the Minister of education and culture regulation number 65 year 2013, it is mentioned that learning tools should be used in learning activities and clearly mentioned in the syllabus, lesson plan; Preparation of learning media and resources, learning appraisal tools, and learning scenarios should be made; Mathematical learning techniques should be made easier and more enjoyable; Mathematical learning should be designed to provide constant enjoyment and comfort for students without imposing any circumstances on them [12] , and among learning media that can be used (other than hand-outs, modules and, books) is student worksheet [13]. 


\section{Research Methods}

This research is a development research using 4D development model (define, design, develop, disseminate) developed by Thiagarajan, Semmel, \& Semmel [17].

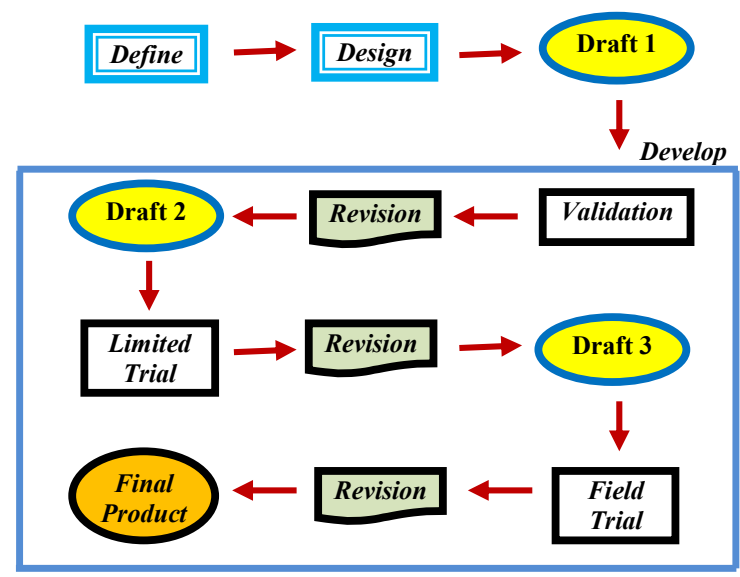

Fig.1: Research Procedure

Subjects in this study were students of class VII MTs Muhammadiyah Karangkajen Yogyakarta Indonesia during the academic year 2018/2019. Samples were taken at random from a group of learners of five study groups. The research was conducted from April to May at even semester of academic year 2018/2019.

The defining stage includes the beginning-end analysis, student analysis, concept analysis, task analysis, and the formulation of learning objectives. Reviewing the junior mathematics curriculum and relevant learning theories were conducted at the beginningend analysis stage. At the same time, the researcher also checks the preparation, implementation, until the results of the learning process and initial observation of mathematical problem-solving. The analysis stage of student demography was conducted to get information about their character covering their background knowledge, cognitive level, and academic ability. Furthermore, determining the composition of the material to be presented to the students depend upon the result of concept analysis. In the task analysis, the researchers obtained details of what tasks should be done by students in learning. The formulation of learning objectives was conducted to obtain indicators of achievement of core competency and basic competencies that based on the previous material analysis.

The design stage includes the preparation of test standards, the selection of media, the selection of existing resource formats which will be developed, and the initial draft. The preparation of this test was based on an indicator of achievement of competence and learning objectives that had been formulated. Selection of media was done to determine the right media in the delivery of learning materials. The selection of formats in the development of this learning tool included formats in terms of designing materia content, selection of strategies or learning models and learning resources. These early drafts included the design of learning tools in the form of Learning Implementation Plans, Student Worksheets, and instruments of creative thinking skills. This initial design result is called draft.

The development stage is the stage to produce the product through two steps: (1) expert appraisal followed by revision and (2) development testing. The assessment of experts/practitioners on learning tools includes formats, languages, illustrations, and content. Based on input from experts, learning materials were revised to make it more precise, effective, easy and technically has high quality. Field trials were conducted to obtain direct input in the form of responses, reactions, student comments, and observers of learning tools that had been prepared.
Instruments for measuring the effectiveness of the devices are developed in the form of a testing instrument of creative thinking ability. It is used to measure students' ability in answering the problem related to some mathematical concepts. The problem is given in a descriptive text. The answer of each item is adjusted to the given problem weight.

The disseminate process was not initiated since it deals with the promotion of the product to the users, whether individual or group Dissemination can be done in other classes in order to know the effectiveness of the use of the device in the learning process. Dissemination can also be done through the transmission process of related learning practitioners in a particular forum. The dissemination aims at getting input, correction, suggestion, and assessment from the end users.

The data in this study were obtained from both testing and nontesting techniques. From the testing technique, it was obtained the students' cognitive thinking ability, from non-testing techniques the researchers found the design validity and practicality. Testing techniques were used to measure its effectiveness while nontesting technique was conducted to obtain; (1) data on the validity of device and instrument including Learning Implementation Plan, Student Worksheet, and student's creative thinking ability test, (2) teacher assessment data, (3) student appraisal data, and (4) data on learning activities.

\section{Results and Discussion}

This study has resulted three kind of instruments,e.i instruments to measure validity, practicality, and effectiveness. Instruments for measuring the validity are validation sheet of the Lesson Plans, the Student Sheet validation, and the validation sheet of the creative thinking ability test. The validation sheet of the Lesson Plans and the Student Worksheet are list of five-page checklists, in which the validator gives a check mark on the selection criteria on each validation sheet. The validation sheet of the mathematical representation capability is also in the form of checklist list for valid and invalid criteria selection. The components assessed on each validation sheet are presented in Table 1 .

\begin{tabular}{|c|c|c|}
\hline \multicolumn{2}{|c|}{ Table 1: Device validity instrument } \\
\hline Number & Instruments & \multicolumn{1}{c|}{ Validity Aspect } \\
\hline 1 & $\begin{array}{c}\text { The validation sheet of the } \\
\text { lesson plans }\end{array}$ & $\begin{array}{l}\text { Identity of Lesson Plan, Lan- } \\
\text { guage, Content covering ob- } \\
\text { jectives, prerequisite materi- } \\
\text { als, learning materials, learn- } \\
\text { ing activities, time allocations, } \\
\text { and benefits/uses }\end{array}$ \\
\hline \multirow{2}{*}{2} & $\begin{array}{c}\text { Student worksheet validation } \\
\text { sheet }\end{array}$ & $\begin{array}{l}\text { Formats, Illustrations, Table } \\
\text { layout and diagrams, Con- } \\
\text { tents, Language snd writing, } \\
\text { Benefit/usage }\end{array}$ \\
& $\begin{array}{c}\text { Test Validation Sheet for } \\
\text { Student Creative Thingking } \\
\text { Skill }\end{array}$ & $\begin{array}{l}\text { Guidance clarity, Content, } \\
\text { and Language used }\end{array}$ \\
\hline \multirow{2}{*}{3} & \multicolumn{2}{|c|}{}
\end{tabular}

To measure the practicality of the design, the teachers and students are demanded to answer teacher's assessment sheets, student assessment sheets, and instructional learning observation sheets. Five-Linker scale was used on all of those assessment sheets. Components assessed on the instrument's practicality are presented in Table 2 .

Table 2: Devalued Instruments and Devices Developed

\begin{tabular}{|c|l|l|}
\hline Number & \multicolumn{1}{|c|}{ Instruments } & \multicolumn{1}{c|}{ Validity Aspect } \\
\hline \multirow{3}{*}{1} & & Learning Implementation \\
& & Plan, Student worksheet, \\
& Teacher Assessment Sheet & Learning implementation, \\
& & Student Response during \\
& & Learning, and Student Crea- \\
\hline
\end{tabular}




\begin{tabular}{|c|c|c|}
\hline 2 & Student Assessment Sheet & $\begin{array}{l}\text { The ongoing Worksheet and } \\
\text { Learning Worksheet }\end{array}$ \\
\hline 3 & $\begin{array}{c}\text { Observation Sheet of Imple- } \\
\text { mentation of Learning }\end{array}$ & $\begin{array}{l}\text { The lesson steps in the Les- } \\
\text { son Plan include the charac- } \\
\text { teristic of Indonesian RME }\end{array}$ \\
\hline
\end{tabular}

Descriptive texts were also applied to the testing of instructional tools, Learning Implementation Plan and Student Worksheet, as well as instruments of creative thinking ability. The validation results showed that the device has met the criteria of validity.

Teacher assessment and student assessment of instructional tools are found practical as each device component meets a minimum category of practical. Then creative thinking ability is said to be effective / completed individually as it reaches the Minimum Exhaustiveness Criteria established by the school of 75 , while the classical effectiveness is achieved if at least $75 \%$ of the test subject subjects reach the individual mastery category.

\section{Conclusions and Recommendations}

This research is about the Design of Student Worksheets based on the Indonesian Realistic Mathematics Education model, the characteristic of the students, and the 2013 curriculum. Student Worksheet guides the students to enjoy the experience on each stage of the learning process and connect with their personal experience. Student Worksheet has the potential to improve students' creative thinking skills. Further research can be executed for the next stage of development and dissemination.

\section{References}

[1] Trilling B \& Fadel C, 21st Century Skill: Learning for Life in Our Times, Jossey-Bass A Wiley Imprint, (2009)

[2] Yuniarti Y, Kusumah YS, Suryadi D \& Kartasasmita BG, "The Effectiveness of Open-Ended Problems Based Analytic-Synthetic Learning on the Mathematical Creative Thinking Ability of PreService Elementary School Teachers", IEJME Mathematics Education, Vol. 12, No. 7, (2017), pp.655-666.

[3] Khoule A, Bonsu NA \& El Houari H, "Impact of Conceptual and Procedural Knowledge on Students Mathematics Anxiety International", Journal of Educational Studies in Mathematics, Vol.4, No.1, (2017), pp.8-18

[4] Fandria V, Sugiman \& Mardapi D, "Development of Mathematics Achievement Test for Third Grade Students at Elementary School in Indonesia", IEJME Mathematics Education, Vol.12, No.8, (2017), pp.769-776.

[5] Busnawir, "Effectiveness of Problem Solving learning approach to Creative Thinking Skill By Taking Into Account To Attitude of students toward Mathematics", Indonesian Journal of Educational Review, Vol.2, No.1, (2015), pp.84-96.

[6] Hasbullah \& Wibawa B, "Analysis of Mathematics Students Ability in Learning Metacognitive Strategy Type IDEAL (Identify, Define, Explore, Act, Look)", IEJME Mathematics Education, Vol.12, No.10, (2017), pp.859-872

[7] Jazuli LOA, Anggo M, Rahim U \& Sahidin L, "The Application of Scientific Plus Learning to Improve Mathematics Learning Achievement of Junior High School Students Grade VII", IEJME Mathematics Education, Vol.12, No.9, (2017), pp.837-844.

[8] Kemdikbud, "Hasil UN 2017", (2017), Downloaded from https://kemdikbud.go.id/main/files/download/9c7fdf36a39328d, Retrieved on April 11, 2018.

[9] PISA, "Result in Focus", (2015), Downloaded from https://www.oecd.org/pisa/pisa-2015-results-in-focus.pdf, Retrieved on April 11, 2018.

[10] International Mathematical Olympiad (IMO), 2017 "Result: Ranking of Countries", (2017), Downloaded from http://imoofficial.org/results.aspx., Retrieved on April 11, 2018.
[11] PP. No 32 year 2013, "Standar Nasional Pendidikan", Downloaded from https://www.slideshare.net/.../pp-no-32-tahun-2013-tentangstandar-nasional-pend, Retrieved on April 11, 2018.

[12] Laurens T, Batlolona FA, Batlolona JR \& Leasa M, "How Does Realistic Mathematics Education (RME) Improve Student's Mathematics Cognitive Achievement?", Eurasia Journal of Mathematyics, Science and Technology Education, Vol.14, No.2, (2018), pp.569-578.

[13] Zulyadaini, "Development of Student Worksheets Based Realistic Mathematics Education (RME)", International Journal of Engineering Research and Development, Vol.13, (2017), pp.1-14.

[14] Zulyadaini, “A Development of Students' Worksheet Based on Contextual Teaching and Learning", International Journal of Learning, Teaching and Educational Research, Vol.16, No.6, (2017), pp.64-79.

[15] Putra H D, Herman T \& Sumarmo U, "Development of Student Worksheets to Improve the Ability of Mathematical Problem Posing", International Journal on Emerging Mathematics Education (IJEME), Vol.1, No.1, (2017), pp.1-10.

[16] Suratno J, "The Development of Students Worksheet Using GeoGebra Assisted Problem-Based Learning and Its Effect on Ability of Mathematical Discovery of Junior High Students", Implementation and education of Mathematics and Science, (2016), Proceeding of 3rd International Conference on Research, UNY.

[17] Thiagarajan S, Semmel D \& Semmel MI, "Instructional development for training teachers of exceptional children: A sourcebook", (1974), Minnesota: Central for Innovation on Teaching the Handicaped Downloaded from https://files.eric.ed.gov/fulltext/ED090725.pdf 